\title{
Anatomical and Histological Characteristics of the Nervous System of the Chilean Giant Mussel, Choromytilus chorus (Molina 1782) (Bivalvia, Mytilidae)
}

\author{
Características Anatómicas e Histológicas del Sistema Nervioso del Mejillón \\ Gigante, Choromytilus chorus (Molina 1782) (Bivalvia, Mytilidae)
}

Maryori Ruiz-Velasquez ${ }^{1,3}$; Hernan Montecinos $^{2} \&$ Eduardo Tarifeño $^{3}$

RUIZ-VELASQUEZ, M.; MONTECINOS, H. \& TARIFEÑO, E. Anatomical and histological characteristics of the nervous system of the Chilean giant mussel, Choromytilus chorus (Molina 1782) (Bivalvia, Mytilidae). Int. J. Morphol., 36(4):1262-1267, 2018.

SUMMARY: The anatomy and histology of the nervous system in the mussel Choromytilus chorus were studied. Juvenile specimens of $C$. chorus and adult broodstock were collected in Laraquete Cove, Chile $\left(37^{\circ} 09^{\prime} \mathrm{S} ; 37^{\circ} 11^{\prime} \mathrm{O}\right)$. The juveniles were used for histological analysis and the adults for a macroscopic description of anatomical. The histological description was carried out by Gallego's trichrome technique. The macroscopic analysis showed that nervous system network includes three pairs of ganglia of orange color and little size (20-40 mm) (cerebral, pedal and visceral) located in the anterior, middle and posterior zone of the specimen, respectively. The histological analysis showed many type de cells inside the ganglia (neurosecretory, granulated and glial cells). The ganglia network could be involving in regulating several physiological processes in the mussels through of their neurosecretions.

KEY WORDS: Mussels; Nervous system; Histology; Neurosecretory cells; Choromytilus chorus.

\section{INTRODUCTION}

The family Mytilidae is an important group within the benthic marine bivalves, with a wide cosmopolitan geographical distribution (Bayne, 1976; Aldea \& Valdovinos, 2005). In Chile, this family includes the species, Semimytilus algosus (Gould 1850), Perumytilus purpuratus (Lamarck 1819), Brachidontes granulata (Hanley 1843), Mytilus chilensis (Hupé 1854), Choromytilus chorus (Molina 1782), Aulacomya ater (Molina 1782) (Zagal \& Hermosilla, 2001; Aldea \& Valdovinos), and the recently found species Mytilus galloprovincialis (Tarifeño et al., 2012). As in many other countries, the Chilean mussels constitute aquaculture resources of great economic importance due to their commercial extraction or their massive sea farming in suspended longline systems (Food and Agriculture Organization of the United Nations, 2014).

Choromytilus chorus stands out because of its ecological and economic importance (Moreno, 1995; Servicio Nacional de Pesca, 2016), and is distributed from Callao (Peru) $\left(10^{\circ} \mathrm{S}\right)$ to the Strait of Magellan and the Beagle Channel in the southeastern Pacific $\left(54^{\circ} \mathrm{S}\right)$ (Osorio et al., 2002). This mussel is gonocoric, their sex ratio is $1: 1$ and size at first maturity ranged from 38-40 mm (Lépez, 2005; Ruiz-Velásquez et al., 2017). Beside its aquaculture relevance, $C$. chorus stands out as an excellent biological models to perform anatomical and experimental studies understanding basic mechanisms of developmental biology and fundamental processes in neuroscience, because its large average size at adult phase.

Although $C$. chorus is important in our country, it is surprising that so little is currently known about of fundamental aspects of its basic biology concerning to nervous system, both of this species as in other mytilidos. There is obviously an increasing need of do studies of basic biology in the mollusks due to strong environmental disturbances and anthropogenic to that currently they are exposed. In this context, this study describes, for the first time, the anatomy and histology of the nervous system of the Chilean giant mussel Choromytilus chorus, with emphasis on their role in reproductive aspects.

\footnotetext{
${ }^{1}$ Programa de Doctorado Ciencias Aplicadas Mención Sistemas Marinos Costeros, Universidad de Antofagasta, Antofagasta, Chile.

${ }^{2}$ Departamento de Biología Celular, Facultad de Ciencias Biológicas, Universidad de Concepción, Chile.

${ }^{3}$ Departamento de Zoología, Facultad de Ciencias Naturales y Oceanográficas, Universidad de Concepción, Chile.
} 


\section{MATERIAL AND METHOD}

C. chorus specimens $(\mathrm{n}=10)$ of 30,40 and $120 \mathrm{~mm}$ shell length of were collected in Laraquete Cove, BíoBío region, Chile ( $37^{\circ} 09^{\prime} \mathrm{S} ; 37^{\circ} 11^{\prime} \mathrm{W}$ ), in October 2011 . The total shell length of each mussel was measured using a Vernier caliper $( \pm 0.1 \mathrm{~mm})$. For the histological analysis, a subset of mussels $(n=3)$ was selected from individuals of $30 \mathrm{~mm}(\mathrm{n}=3)$ and $40 \mathrm{~mm}$ shell length, that were classified as juveniles and adults in their first sexual maturity (Lépez). Meanwhile, individuals $120 \mathrm{~mm}(\mathrm{n}=4)$ were used to perform anatomic descriptions of the nervous system through visual inspection and bisection under a stereoscopic magnifying glass.

The whole specimens were fixed in a solution of 10 $\%$ formalin in sea water for $48 \mathrm{~h}$. The samples were then dehydrated by immersion for one hour each in alcohols, and benzol. The samples were then embedded in paraffin, and a series of $7 \mu \mathrm{m}$ slides were made with a microtome (Leica Autocut 2040) in the transverse and sagittal plane. The slides sections were then stained with Gallego's trichrome staining following Gallardo (2001) and observed under an optical microscope.

\section{RESULTS}

Macroscopic analysis of the nervous system network of the mussel C. chorus. The nervous system of the C. chorus mussel showed to be bilaterally symmetrical, according to a sagittal plane with respect to the main axis of the organism. It consists of three pairs of ganglia of orange color: cerebral (CG), pedal (PG) and visceral (VG). The CG is located in the anterior area above the esophagus (near the labial palps), the PG is placed in the middle (under foot organ) and the VG is in the posterior area (on the middle area of the adductor muscle) of the individual. Each pair of ganglia is connected to each other by connective nerves and bilaterally by inter-ganglionic nerve commissures (Fig. 1).

The cerebral ganglia are connected by a long dorsal commissure known as inter-cerebral which passes over the esophagus, they have rectangular shape and are located parallel to the mouth close to the area where the lip palps originate. From each ganglion emerges the anterior pallial nerve (APN) toward the anterior region of the mantle, ramifying by all the edge of this and later joining with the posterior pallial nerve PPN (coming from the visceral ganglion) to form circumpallial nerves $(\mathrm{CP})$. Branches of the buccal nerves $(\mathrm{BN})$ to innervate of the labial palps are also observed from these ganglia. In addition, from each cerebral ganglion emerge two nerves in independent form, one that connects with the pedal ganglion and another with the visceral ganglion, called cerebro-pedal connectives (CPC) and cerebro-visceral connectives (CVC), respectively (Figs. 1A-B).

The pedal ganglia are fused in the midline, although the right and left bodies are distinguishable. This pair of ganglia have twice the size of the cerebral and visceral ganglia, and are located at the base of the pedal organ (foot) attached to the first pair of anterior retractor muscles of the byssus. From each ganglion emerges the pedal nerves, which penetrate to the posterior pedal retractor muscles and enter the foot. In addition, from this nerve emerge the dorsal retractor byssus nerves (DRBN), supplying part of the posterior retractor byssus musculature and ventral retractor byssus nerves (VRBN), which supply the byssus organ and parts of the anterior and posterior retractor byssus muscles. From the anterior region of this ganglion emerge the brain-pedal connective nerve (BPCN) (Figs. 1A-1C).

The visceral ganglions are ovoid-shape are connected by a short inter-ganglionic commissure. They are located on the anterior-ventral side of the posterior adductor muscle and they are within of the gill insertion area. Ventral pallial nerves (VPN) (which have dorsal and ventral branches dorsal pallial nerves to the edge of the mantle), dorsal pallial nerves to the edge of the mantle (DPN), posterior renal nerves (RN) and posterior pedal nerves (PPN), also were observed in these ganglia. In addition, from this nerve emerge several gill nerves (GN), supplying the musculature and epithelium of the gill. From the anterior region emerges the cerebral-visceral connective nerve $(\mathrm{CVCN})$ and from the posterior region a pair of nerves that go to the posterior region of the mantle (posterior pallial nerve), which join with the pallial nerves coming from the cerebral ganglia (Figs. 1A-1D).

Histological analysis of the Nervous System Network of the mussel $C$. chorus. The three ganglia and nerves are covered by a thin layer of lax connective tissue in the periphery, denominated "perineural" with a main function to protect the nerve structures. The ganglia are composed of a central nucleus called neuropilo, which presents numerous and tight nerve fibers and is surrounded by cells of different size, that together form a structure called cortex (Figs. 2-3-4). In the cortex of all ganglia, three cell types of different sizes were observed: i) large cells with abundant cytoplasm, and triangular and elongated shape of $10 \mathrm{~mm}$ of average size, characterized by a large nucleus $(6 \mathrm{~mm})$ highly euchromatinic with an evident nucleolus, resembling neurosecretory "type A" cells described by Gallardo in the mussel Semimytilus algosus; ii) rounded cells of scarce cytoplasm, 6-7 $\mathrm{mm}$ in average size, known as "granular cells", and iii) cells of small size 3-4 mm on average, known as "glial cells" (Figs. 2C). 


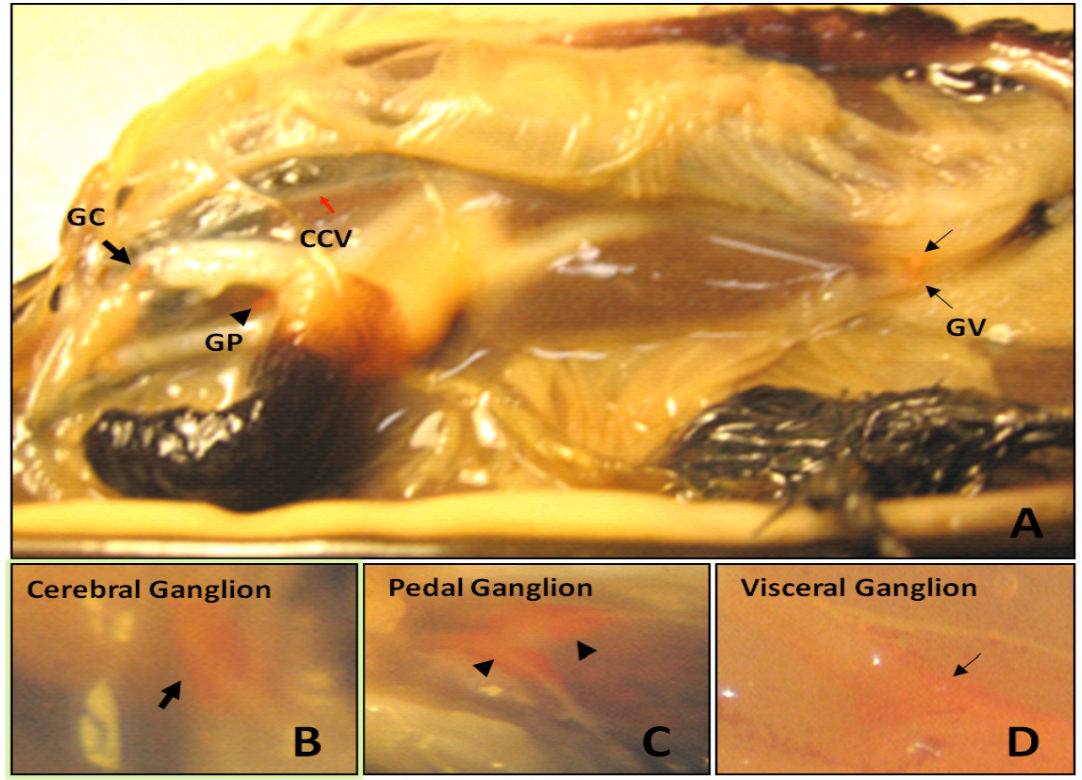

Fig. 1. Macroscopic analysis of the location of the ganglia of the mussel Choromytilus chorus. A) magnification of the sagittal plane that allows observing the location of the cerebral ganglia $(\mathrm{CG})$, pedal ganglion $(\mathrm{PG})$, visceral ganglion $(\mathrm{VG})$ and the visceral connective nerve( $\mathrm{VCN})$. (B-D) further increase of the respective ganglion.
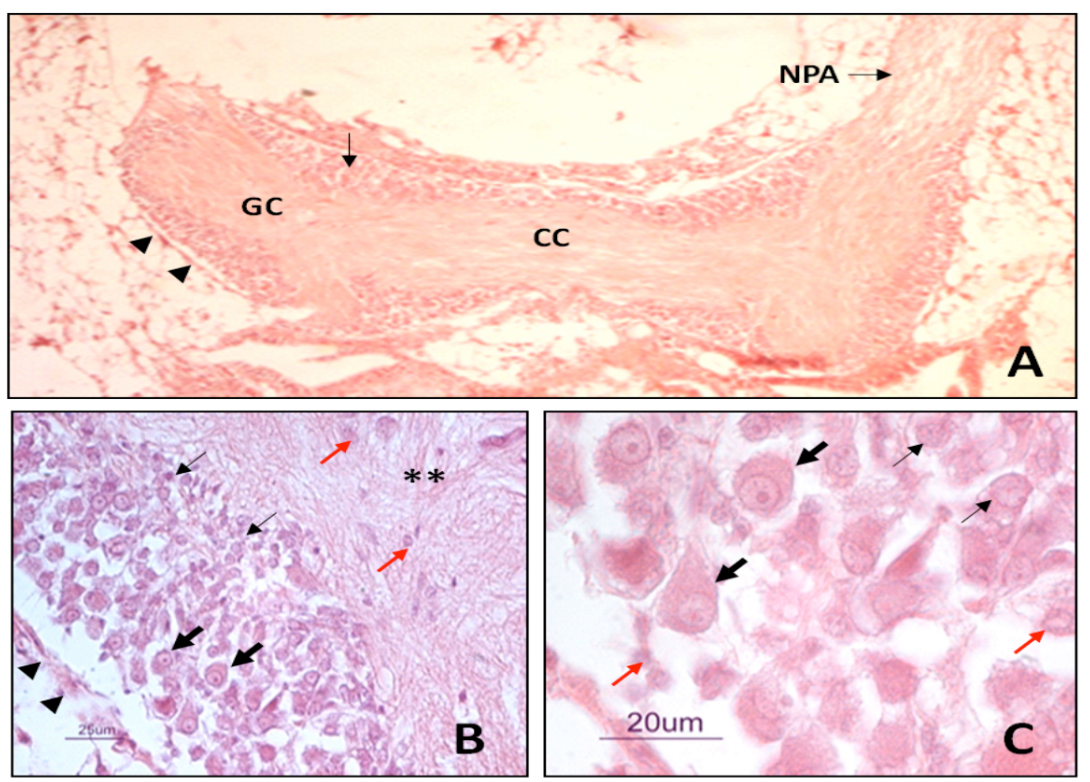

Fig. 2. Transverse section of the brain ganglia (CG) stained with Gallego's trichrome A) Low magnification shows the neural tissue surrounded by a connective capsule (arrowhead), the two ganglions joined by a fibrous commissure (CC) and the projection of the anterior pallial nerve (APN). (B-C) the ganglionic tissue shows a fibrous internal area (asterisk) and a very cellular external area, where they differentiate neurons (arrows) and medium size (small arrow) and abundant glial cells (red arrows).

The commissures, connectives and nerves have a thin layer of loose connective tissue at the periphery and bundles of fibers in the center (Figs. 2A and $4 \mathrm{C}$ ). Cerebral ganglia presented a thick bridge of neuropilus that connects them called the intercerebral commissure, in the anterior area of this pair of ganglia, the anterior pallial nerves emerge (Fig. 1A) and in the posterior limb are the posterior pallial connective nerves. Pedal ganglia did not shown an inter-ganglionar commissure and both bodies could be seen separated by a thin perineural band (Fig. 3A). In addition, the onset of the pedal nerve that innervates the foot of these organisms, was observed (Fig. 3D).

In $C$. chorus, the visceral ganglia are associated with the adductor posterior muscle, having neurosecretory cells located preferentially in the dorsal area (Fig. 4). In C. chorus, individuals in juvenile phase had a lower amount of neurosecretory cells and a cytoplasm less developed than to individuals in first sexual maturity, as it was observed in juveniles of S. algosus (Gallardo).

\section{DISCUSSION AND CONCLUSION}

The nervous system is a key agent for coordinating and regulating physiological functions in the invertebrates (e.g., reproduction, feeding, metabolism and behavioral) by connection between the external environment and internal processes in response to environmental variations (temperature and salinity) (Mathieu et al., 1991). The perception of external stimulation in molluscs is captured and channeled by cells and/or highly specialized organs (thermal receptors, statoreceptors, and paleal sensory organ), located mainly on the edge of the bivalve mantle (Zaixo, 2003) which transmit the information from the periphery toward nerve centers (ganglia), that in response synthesize and release different types of chemical messengers or neurosecretions for controlling the activity of target tissues as a specific response (Mathieu et al.).

In this study, the juveniles and adults stages presented a nervous network system fully formed, and their anatomy 

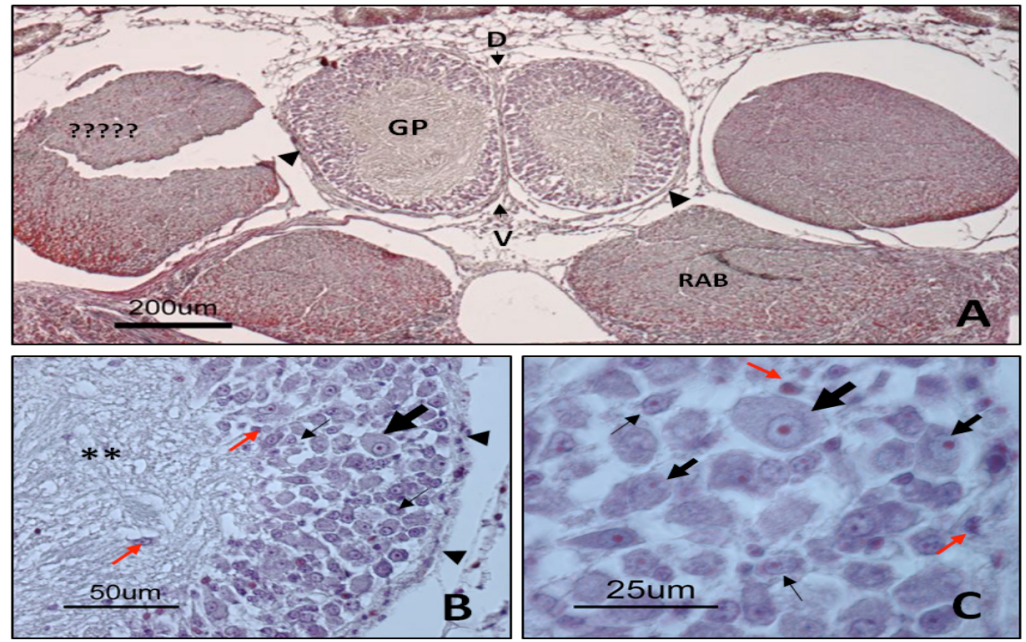

Fig. 3. Transverse section of the pedal ganglia (PG) stained with Gallego's trichrome A) Low magnification shows the neural tissue surrounded by a conjunctive capsule (arrowhead), the two ganglia are close to the anterior retractor muscles of the byssus $(\mathrm{RAB})$ and the retractor muscles of the foot (RFM).It highlights the differential distribution of the cellular component of the cortex in the ventral (V) and dorsal region (D). (B-C) The ganglion tissue shows a fibrous internal zone (asterisks) and a very cellular external zone, where we can differentiate three types of neurons; large (medium arrows), small (small arrows), and abundant glial cells (red arrows).
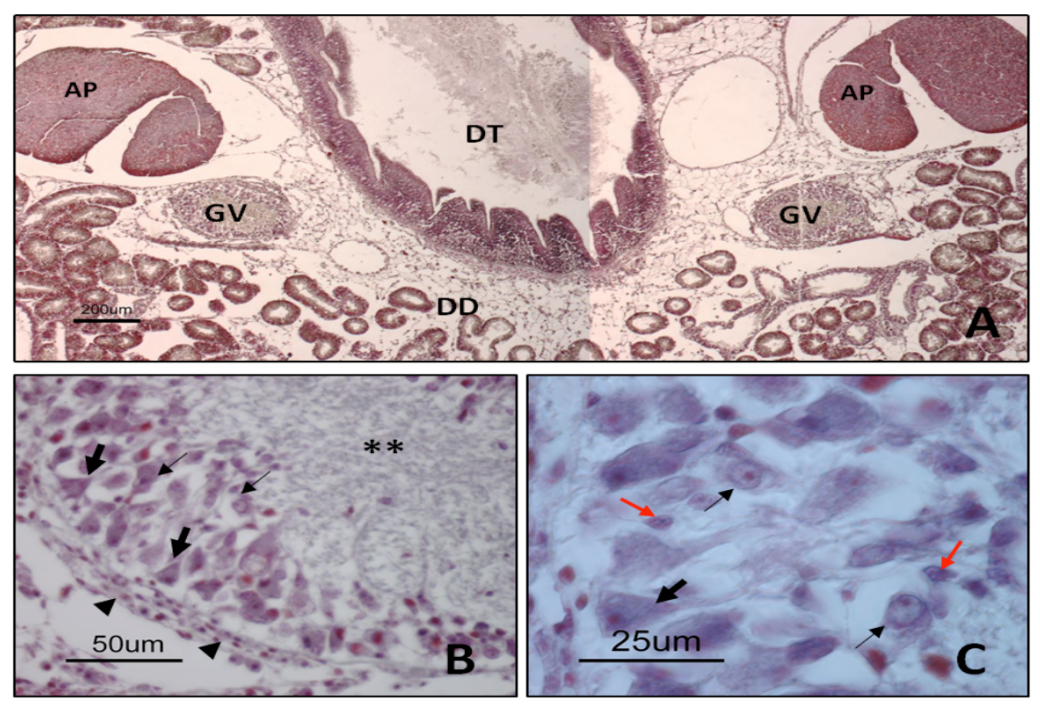

Fig. 4. Transverse section of visceral ganglia stained with Gallego's trichrome. A) Low magnification shows the neural tissue constituted by two small ganglia (VG), close to digestive structures and the posterior abductor muscles (AP). (BC) The ganglionic tissue shows a fibrous internal zone (asterisks) and a very cellular external zone, where large neurons of a pyramid-shaped (thick arrows) and small with rounded appearance (medium arrow) are observed, in addition to abundant glial cells (red arrows). Capsule of the connective tissue (arrow head). Abbreviations: S: stomach, DD: digestive diverticulum.

and spatial distribution were similar in both stages. In bivalve, the formation of the nervous system occurs early during its ontogenetic development, the appearance of the first neurons that constituting the nerve ganglia occurs in trochophore larva stage (Croll \& Dickinson, 2004). Choromytilus chorus has a nervous network system similar in form and structure to other species of the family Mytilidae (Bayne; Gallardo; Zaixso, 2003); Mytilus edulis (Gosling 1992), Mytilus californianus (Smith, 1997), Semimytilus algosus and Aulacomya ater. However, in $C$. chorus as in A. ater it was observed that both the cerebral-pedal and cerebral-visceral connective nerves are not fused to a common axis, but they emerge after the origin of the cerebral ganglia as has been described for others species of the genus Mytilus (List, 1902; Field, 1922).

Choromytilus chorus has ganglion and nerve structures that are innervating important organs, as such as the pedal ganglion with the anterior muscles of the byssus retractor and muscles of the foot. Studies of removal of nerve centers in Mytilus edulis showed that the retraction of the foot is controlled almost entirely by reflex arches from the pedal ganglion, although in other species seems to be involved the cerebral ganglion (Bayne). Meanwhile, the visceral ganglion controls the cardiomodulation (Kodirov, 2011) and movement of the valves, mantle, siphons and gills in mollusks (Bayne). The brain ganglion seems to control the gonadic tissue through neurosecretions and nerve endings and the fibers of the byssus (Mathieu et al.).

The histological analysis showed the presence of at least three different cell types in the ganglions: granular, glial and neurosecretory. This latter, showed anatomical feature (abundant cytoplasm, core eucromatinic, nucleolus evident, size and shape) similar to that reported for neurosecretory cells of other species of the family Mytilidae (Gallardo; Zaixso). The neurosecretory cells may also be involved in regulating various physiological processes in this mussel, for example, the neurosecretion in lamellibranches has been associated with the control of the gonadal mitosis, glycogen metabolism, ciliary activity, growth, mobility, responses to environmental stress (e.g, salinity and temperature) and in particular on changes related to the ontogenetic development of this individuals (Mathieu et al.; Carroll \& Catapane, 2007). 
The close correlation between the annual neurosecretory cycle of the "type al cells" and the gametogenic cycle has suggests a possible role of these cells in the control of the reproduction in mytilids; secretory material is accumulated in the cerebral ganglia (contain $75 \%$ of the neurosecretory cells) during gametogenesis and then evacuated from the cells when the gametes become fully mature (Mathieu et al.). The results of this study suggest that the secretion of this type of cells would be regulating reproductive processes in $C$. chorus, because individuals in juvenile phase had a lower amount of neurosecretory cells (type A1 cells), specially in the cerebral ganglion, and a cytoplasm less developed compared to individuals in first sexual maturity, as has been observed by in juveniles of $S$. algosus Gallardo.

The neurosecretory cells presents in the nervous ganglion of $C$. chorus could have peptides analogous to the vertebrate, as has been established in several species of mollusks (Bayne; Mathieu et al.). For example, in several species of bivalves has been observed the presence of peptides, as such as insulin-like IGFs in the cerebral ganglia of Mytilus edulis (Kellner-Cousin et al., 1994), somatostatin GHIH and cholecystokinin CCK in the cerebral ganglia of Mytilus edulis (Mathieu \& Van Minnen, 1989), melanocyte stimulating hormone HSM in the pedal ganglia (Mathieu et al.), gonadotropin-releasing hormone GnRH in Patinopecten yessoensis (Pazos \& Mathieu, 1999; Nakamura et al., 2007), FMRFamide in Mytilus edulis (Favrel et al., 1998), APGWamide in Placopecten magellanicus (Smith et al.) and serotonin (5-HT) in Patinopecten yessoensis and Mytilus edulis (Matsutani \& Nomura, 1986).

In conclusion, the results of this study have shown that the anatomical and histological characterizations of the nervous system of $C$. chorus are similar to the descriptions made for other species of mytilids, differing only in the absence of a common axis of the connective tissues cerebral-visceral nerves and brain-pedals, just as happens in Aulacomya ater. However, it is essential to continue research in this area, especially in studies relating to the receptors and neurotransmitters that allow understanding the internal mechanisms and signaling ways that are related to the environment.

\section{ACKNOWLEDGEMENTS}

This work was carried out in the Histological Laboratory of the Department of Cellular Biology, University of Concepcion, headed by Dr. H. Montecino and Laboratory of Marine Animal Physiology, Department of Zoology, heade by Dr. E. Tarifeño.
RUIZ-VELASQUEZ, M.; MONTECINOS, H. \& TARIFEÑO, E. Características anatómicas e histológicas del sistema nervioso del mejillón gigante, Choromytilus chorus (Molina 1782) (Bivalvia, Mytilidae) Int. J. Morphol., 36(4):1262-1267, 2018.

RESUMEN: Se estudió la anatomía e histología del sistema nervioso en el coro Choromytilus del mejillón. Se recolectaron especímenes juveniles de C. coros y reproductores adultos en Laraquete Cove, Chile $\left(37^{\circ} 09^{\prime} \mathrm{S}, 37^{\circ} 11^{\prime} \mathrm{O}\right)$. Los especímenes juveniles se utilizaron para el análisis histológico y los adultos para una descripción macroscópica de anatómica. La descripción histológica se realizó mediante la técnica de tricrómico de Gallego. El análisis macroscópico mostró que la red del sistema nervioso incluye tres pares de ganglios de color naranjo y poco tamaño (20-40 mm) (cerebral, pedal y visceral) localizados en la zona anterior, media y posterior de la muestra, respectivamente. El análisis histológico mostró muchos tipos de células dentro de los ganglios (células neurosecretoras, granuladas y gliales). La red de ganglios podría estar involucrada en la regulación de varios procesos fisiológicos en los mejillones a través de sus neurosecreciones.

PALABRAS CLAVE: Mejillones; Sistema nervioso; Histología; Células neurosecretoras; Coro Choromytilus.

\section{REFERENCES}

Aldea, C. \& Valdovinos, C. Moluscos del intermareal rocoso del CentroSur de Chile $\left(36^{\circ}-38^{\circ} \mathrm{S}\right)$ : taxonomía y clave de identificación. Gayana (Concepc.), 69(2):364-96, 2005.

Bayne, B. L. Marine Mussels, their Ecology and Physiology. New York, Cambridge University Press, 1976.

Carroll, M. A. \& Catapane, E. J. The nervous system control of lateral ciliary activity of the gill of the bivalve mollusc, Crassostrea virginica. Comp. Biochem. Physiol. A Mol. Integr. Physiol., 148(2):445-50, 2007.

Croll, R. P. \& Dickinson, A. J. G. Form and function of the larval nervous system in molluscs. Invertebr. Reprod. Dev., 46(2-3):173-87, 2004.

Favrel, P.; Lelong, C. \& Mathieu, M. Structure of the cDNA encoding the precursor for the neuropeptide FMRFamide in the bivalve mollusc Mytilus edulis. Neuroreport, 9(13):2961-5, 1998.

Field, I. A. Biology and economic value of the sea mussel Mytilus edulis. Bull. Bur. Fish., 38(1):127-259, 1922.

Food and Agriculture Organization of the United Nations (FAO). FAO Yearbook. Fishery and Aquaculture Statistics 2012. Rome, Food and Agriculture Organization of the United Nations, 2014. Available from: http://www.fao.org/3/a-i3740t.pdf

Gallardo, C. Control de Células Neurosecretoras sobre el Proceso Gametogénico en Semimytilus algosus Gould 1850 (Bivalvia: Mytilidae). Tesis para optar al título de Biólogo Marino. Antofagasta, Universidad Católica del Norte, 2001.

Kellner-Cousin, K.; Mialhe, E. \& Mathieu, M. Identification of insulinlike peptides in cerebral ganglia neurosecretory cells of the mussel Mytilus edulis. Tissue Cell, 26(6):891-9, 1994.

Kodirov, S. A. The neuronal control of cardiac functions in Molluscs. Comp. Biochem. Physiol. A Mol. Integr. Physiol., 160(2):102-16, 2011.

Lépez, I. Biotecnología Aplicada a la Producción de Choro Zapato (Choromytilus chorus) para Potenciar su Cultivo en Chile. Proyecto Fondef. Concepción, Universidad de Concepción, 2005.

List, T. Die Mytiliden des Golfes von Neapel und der angrenzenden MeeresAbschnitte. Fauna und Flora des Golfes Neapel und der angrenzenden Meeres- Abschnitte. I. Mitt. Zool. Stn. Neapel., 27:1-312, 1902. 
Mathieu, M.; Robbins, I. \& Lubet, P. The neuroendocrinology of Mytilus edulis. Aquaculture, 94:213-23, 1991.

Mathieu. M. \& Van Minnen, J. Mise en evidence par immunocytochimie des cellules neurosecretrices peptidergiques dans les ganglions cerebro'ides de la moule Mvfilus edulis. C. R. Acad. Sci., Paris, 308:48994, 1989.

Matsutani, T. \& Nomura, T. Serotonin-like immunoreactivity in the central nervous system and gonad of the scallop, Patinopecten yessoensis. Cell Tissue Res., 244(3):515-7, 1986.

Moreno, C. A. Macroalgae as a refuge from predation for recruits of the mussel Choromytilus chorus (Molina, 1782) in Southern Chile. J. Exp. Mar. Biol. Ecol., 191(2):181-93, 1995.

Nakamura, S.; Osada, M. \& Kijima, A. Involvement of GnRH neuron in the spermatogonial proliferation of the scallop, Patinopecten yessoensiss. Mol. Reprod. Dev., 74(1):108-15, 2007.

Osorio, R. C. Moluscos Marinos en Chile. Especies de Importancia Económica. Santiago de Chile, Facultad de Ciencias, Universidad de Chile, 2002.

Pazos, A. J. \& Mathieu, M. Effects of five natural gonadotropin-releasing hormones on cell suspensions of marine bivalve gonad: stimulation of gonial DNA synthesis. Gen. Comp. Endocrinol., 113(1):112-20, 1999.

Ruiz-Velásquez, M.; Zapata, M.; González, M. T.; Ordenes, D. \& Escalona, M. Sexual differentiation and size at first maturity of the mussel Choromytilus chorus (Molina, 1782) (Mollusca, Bivalvia) in Northern Chile. Am. Malacol. Bull., 35(1):31-41, 2017.

Servicio Nacional de Pesca (SERNAPESCA). Anuario Estadístico de Pes$c a$. Santiago de Chile, Servicio Nacional de Pesca, Ministerio de Economía, Fomento y Turismo, Gobierno de Chile, 2016.

Smith, S. A.; Nason, J. \& Croll, R. P. Detection of APGWamide-like immunoreactivity in the sea scallop, Placopecten magellanicus. Neuropeptides, 31(2):155-65, 1997.

Tarifeño, E.; Galleguillos, R.; Llanos-Rivera, A.; Arriagada, D.; Ferrada, S.; Canales-Aguirre, C. B. \& Seguel, M. Erroneous identification of the mussel, Mytilus galloprovincialis (Lamarck 1819) as the specie, Mytilus chilensis (Hupe 1854) in the Bay of Concepcion, Chile. Gayana (Concepc.), 76(2):167-72, 2012.

Zagal, C. \& Hermosilla, C. Guía de Invertebrados Marinos del Sur de Chile. Valdivia, Universidad Austral de Chile, 2001.

Zaixso, H. E. Sistema nervioso y receptores en la cholga, Aulacomya atra atra (Bivalvia: Mytilidae). Rev. Biol. Mar. Oceanogr., 38(2):43-56, 2003.

\author{
Corresponding author: \\ Maryori Ruiz-Velasquez \\ Departamento de Zoología \\ Facultad de Ciencias Naturales y Oceonográficas \\ Universidad de Concepción \\ Casilla $160-\mathrm{C}$ \\ Concepción \\ CHILE
}

Email: maryruizvelasquez@gmail.com

Received: 08-05-2018

Accepted: 30-07-2018 